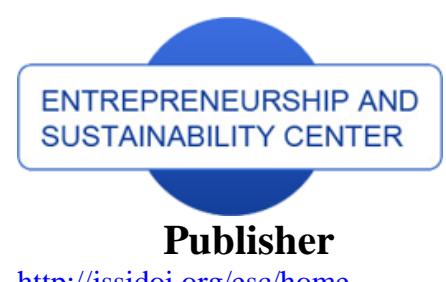

$\underline{\text { http://jssidoi.org/esc/home }}$ enterprise

europe

network

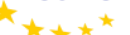

Business Support on Your Doorstep

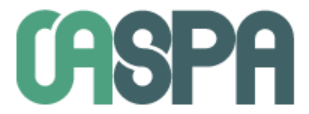

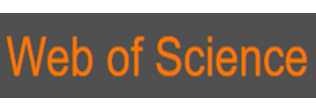

Clarivate
Analytics

\title{
PERSPECTIVES OF SOLVING THE PROBLEMS OF REGIONAL DEVELOPMENT WITH THE HELP OF NEW INTERNET TECHNOLOGIES
}

\author{
Yulia V. Ragulina ${ }^{1}$, Elena I. Semenova ${ }^{2}$, Irina A. Zueva ${ }^{3}$, Elena V. Kletskova ${ }^{4}$, Elena N. Belkina ${ }^{5}$ \\ 1,2 Federal State Budgetary Scientific Institution "Federal Research Center of Agrarian Economy and Social \\ Development of Rural Areas - All Russian Research Institute of Agricultural Economics”, Moscow, Russia \\ ${ }^{3}$ Moscow Witte University, Moscow, Russia \\ ${ }^{4}$ Federal State Budget Educational Institution of Higher Education “Altai State University”, Barnaul Russia \\ ${ }^{5}$ Kuban State Agrarian University, Krasnodar, Russia \\ E-mails: ${ }^{1}$ julra@list.ru, ${ }^{2}$ esemenova@bk.ru, ${ }^{3}$ jzueva@muiv.ru, ${ }^{4}$ stroiteleva_ev@mail.ru, ${ }^{5}$ enbelkina@list.ru
}

Received 10 March 2018; accepted 20 June 2018; published 30 June 2018

\begin{abstract}
The purpose of the work is to determine the key problems of regional development in modern Russia and to substantiate the perspectives and model the process of their solving with the help of new Internet technologies. For full coverage of the problems of regional development in modern Russia, they are analyzed from the positions of public perception and level of dynamics of the statistical data that characterize these problems. At that, the methods of logical and statistical analysis are used. The information and analytical basis of the research includes the materials of the All-Russian Public Opinion Research Center, Federal State Statistics Service of the Russian Federation, and independence expert and analytical organization RIA Ranking for 2014-2017. As a result, the authors substantiate that implementation of new Internet technologies is a perspective means of solving the problems of regional development in modern Russia. These problems concern optimality of interaction of non-government economic subjects (society and entrepreneurship) between each other, which leads to low business activity, complexity of employment, and low income, and non-optimality of interaction between nongovernment economic subjects and the state, which leads to inaccessibility and low quality of state services and public benefits, including healthcare, communal and housing sphere, infrastructure, etc. Implementation of new Internet technologies into entrepreneurship allows reducing its capital intensity, increasing business activity, simplifying the process of employment, and increasing accessibility (reduce cost) of goods and services for the population. Due to implementation of new Internet technologies into activities of state organizations, which provide state services and public benefits, their controllability and manageability by society is achieved - which stimulates increase of their quality and accessibility. A proprietary model of solving the problems of regional development in modern Russia with the help of new Internet technologies is developed.
\end{abstract}

Keywords: problems of regional development; Internet technologies; modern Russia; sustainable entrepreneurship

Reference to this paper should be made as follows: Ragulina, Y.V.; Semenova, E.I.; Zueva, I.A.; Kletskova, E.V.; Belkina E.N. 2018. Perspectives of solving the problems of regional development with the help of new internet technologies, Entrepreneurship and Sustainability Issues 5(4): 890-898. http://doi.org/10.9770/jesi.2018.5.4(13)

JEL Classifications: R11, L86 


\section{Introduction}

Under the influence of globalization of the world economic system, its participants are aggregated and enlarged as well as their interests. National and supra-national (international) regulators focus on the global problems of humanity, as they are the largest and their successful solution is possible only with joint efforts of the global society. However, these problems, despite their global status, are manifested in different ways and have different meanings in modern socio-economic systems.

Orienting at solving the global problems of humanity, national regulators often redistribute resources of national economy in favor of support of economies of other countries. Acting in the interests of prevention of new global crises, they may insufficient attention to the problems of development of domestic socio-economic systems, which contradicts the interests of their population. As a result, the positive effect, which is visible at the global level, could be zero or negative at the national level.

Thus, a new problem of modern times appears - it also deserves the global status, as it is observed everywhere and has the key role for humanity. This is insufficient attention of national regulators to internal problems, which is manifested at the level of regions in the national economic system, which leads to reduction of living standards of population. That's why problems of regional development of modern developed and developing countries deserve the same attention as the global problems of modern times, which are manifested and solved in the third world countries.

The working hypothesis of the research is that a perspective means of solving the problems of regional development in modern developed and developing countries is implementation of new Internet technologies. The research object in this work is modern Russia - it has an intermediate position between developed and developing countries. The purpose of the work is to determine the key problems of regional development in modern Russia and to substantiate perspectives and modeling of the process of solving them with the help of new Internet technologies.

\section{Materials and method}

Problems of regional development of modern developed and developing countries are studied in the works (Golikova et al., 2018), (Golova et a., 2017), Prangishvili et al., 2017), and (Shahraki, 2017). Possibilities and perspectives of using new Internet technologies are studied in the works of such authors as (Inshakova et al., 2017), (Kravets et al., 2013), (Kuznetsov et al., 2016), (Popova et al., 2015), (Przhedetskaya and Akopova, 2016), (Sibirskaya and Shestaeva, 2016), and (Sukhodolov et al., 2018), (Ragulina et al., 2018), (Bogoviz et al., 2017), (Bogoviz et al., 2016), (Zemlickiene et al., 2017), (Tvaronavičienė et al., 2018).

As a result of performed literature overview, it is possible to conclude that components of the selected topic have been studied separately, whole the comprehensive scientific view on the perspectives of solving the problems of regional development with the help of new Internet technologies has not yet been formed, which leads to the need for complex research on this topic.

For the purpose of full coverage of the problems of regional development in modern Russia, here they are analyzed from the positions of public perception (qualitatively) and from the positions of the level and dynamics 
of values of statistical data that characterize these problems (quantitatively). At that, the methods of logical and statistical analysis are used. The information and analytical basis of the research includes the materials of the AllRussian Public Opinion Research Center, Federal State Statistics Service of the Russian Federation, and independence expert and analytical organization RIA Ranking for 2014-2017. The statistical data are given in Table 1.

Table 1. Dynamics of value of the indicators of socio-economic regional development in Russia in 2014-2017

\begin{tabular}{|c|c|c|c|c|}
\hline Indicators & 2014 & 2015 & 2016 & 2017 \\
\hline $\begin{array}{l}\text { Real money income, } \\
\% \text { to previous year }\end{array}$ & 99.3 & 96.8 & 94.2 & 98.3 \\
\hline $\begin{array}{l}\text { Ratio of those involved in region's economy to the number of } \\
\text { population of working age, } \%\end{array}$ & 80.1 & 80.6 & 86.1 & 85.4 \\
\hline Coefficient of tension in the labor market & 2.1 & 3.3 & 3.3 & 2.7 \\
\hline Share of profitable companies, $\%$ & 65.4 & 65.8 & 66.0 & 66.1 \\
\hline $\begin{array}{l}\text { Share of housing fund with all types of utilities, in aggregate area of } \\
\text { housing fund, } \%\end{array}$ & 63.5 & 61.1 & 65.5 & 66.0 \\
\hline
\end{tabular}

Source: compiled by the authors based on: (Federal State Statistics Service, 2018), (RIA Ranking, 2018).

\section{Results}

The actual problems of Russians, which were determined in the course of sociological survey by the All-Russian Public Opinion Research Center in 2017, are structured and presented in Figure 1.

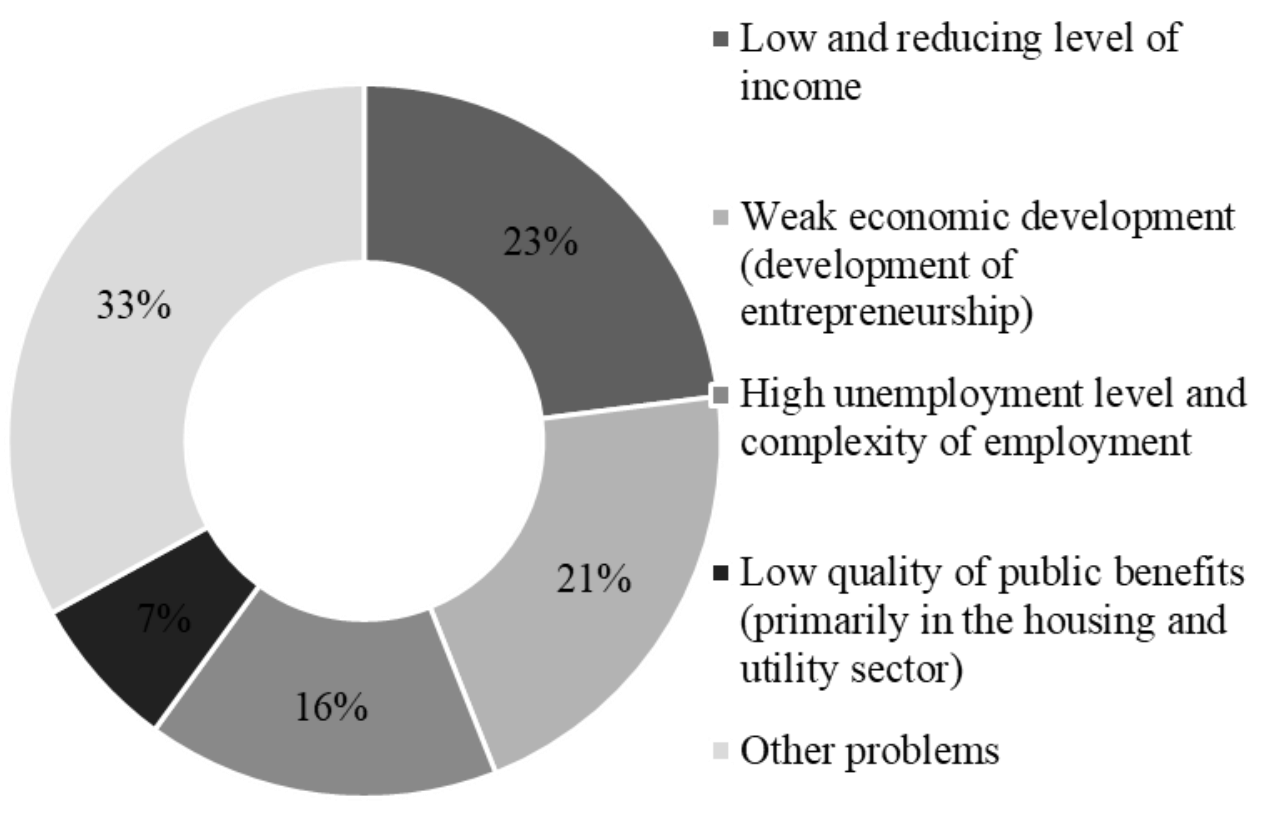

Fig. 1. Structure of actual problems of Russians in 2017. 
Let us study the determined problems in detail. The main problem $(23 \%)$ of regional development in modern Russia is low and reducing level of income. Statistical data of the Federal State Statistics Service confirm existence and deepening of this problem in Russia. Thus, in 2014-2017 there was annual reduction of the level of real income of population. In 2017, it constituted 1.7\% (Federal State Statistics Service, 2018).

The second position (21\%) belongs to the problem of weak economic development, which is expressed in low level and rate of development of entrepreneurship in regions of Russia. According to the Federal State Statistics Servicea, share of profitable companies on average for Russia's regions grows annually (average annual growth rate is $0.35 \%$ ) but is at the low level. Thus, in 2017 the share of profitable companies in Russia constituted $66.1 \%$ (Federal State Statistics Service, 2018), which shows unfavorable business climate and low effectiveness of entrepreneurial activities.

The third (16\%) problem that troubled Russians in 2017 was high employment rate and complexity of employment. According to the Federal State Statistics Service, ratio of the employed in region's economy to the number of population in working age grows, constituting 85.4\% in 2017 (Federal State Statistics Service, 2018). This means that $14.6 \%$ of able-bodied citizens do not have a job. In addition to this, coefficient of tension in the labor market, which is calculated as ratio of average annual number of the unemployed to average annual number of vacancies, provided by employers to state employment services, grows annually, constituting 2.7 in 2017 (Federal State Statistics Service, 2018). That is, the number of unemployed exceeds the number of official jobs by 2.7, which shows large urgency of the problem of unemployment in Russia.

The fourth position (7\%) among the urgent problems that troubled Russians in 2017 belongs to the problem of low quality of public benefits, primarily - in the sphere of housing and communal services, which should be treated as infrastructure on the whole. According to the materials of the Federal State Statistics Service, the share of housing fund, provided with all forms of urban amenities, grows annually, constituting 66\% in 2017 (Federal State Statistics Service, 2017). Therefore, 34\% of the housing fund needs renovation. Other problems, which account for $33 \%$, include the problems of inaccessibility and low quality of medical and other state services.

As a result of systematization of the determined problems of regional development in modern Russia, we determined two main categories, which reflect the reasons for their emergence. The first category: non-optimality of interaction between non-government economic subjects (society and entrepreneurship). It includes the problem of low level of development of entrepreneurship, which leads to the problem of unemployment and low incomes.

The second category: non-optimality of interaction between non-government economic subjects and the state (suppliers of government services and public benefits, which are related to the state not according to the property form but according to specialization for execution of state functions). It includes the problem of inaccessibility and low quality of state services and public benefits, including healthcare, housing and utility sector, infrastructure, etc.

The model of complex solution of the above problems of regional development in modern Russia with the help of new Internet technologies is presented in Figure 2. 


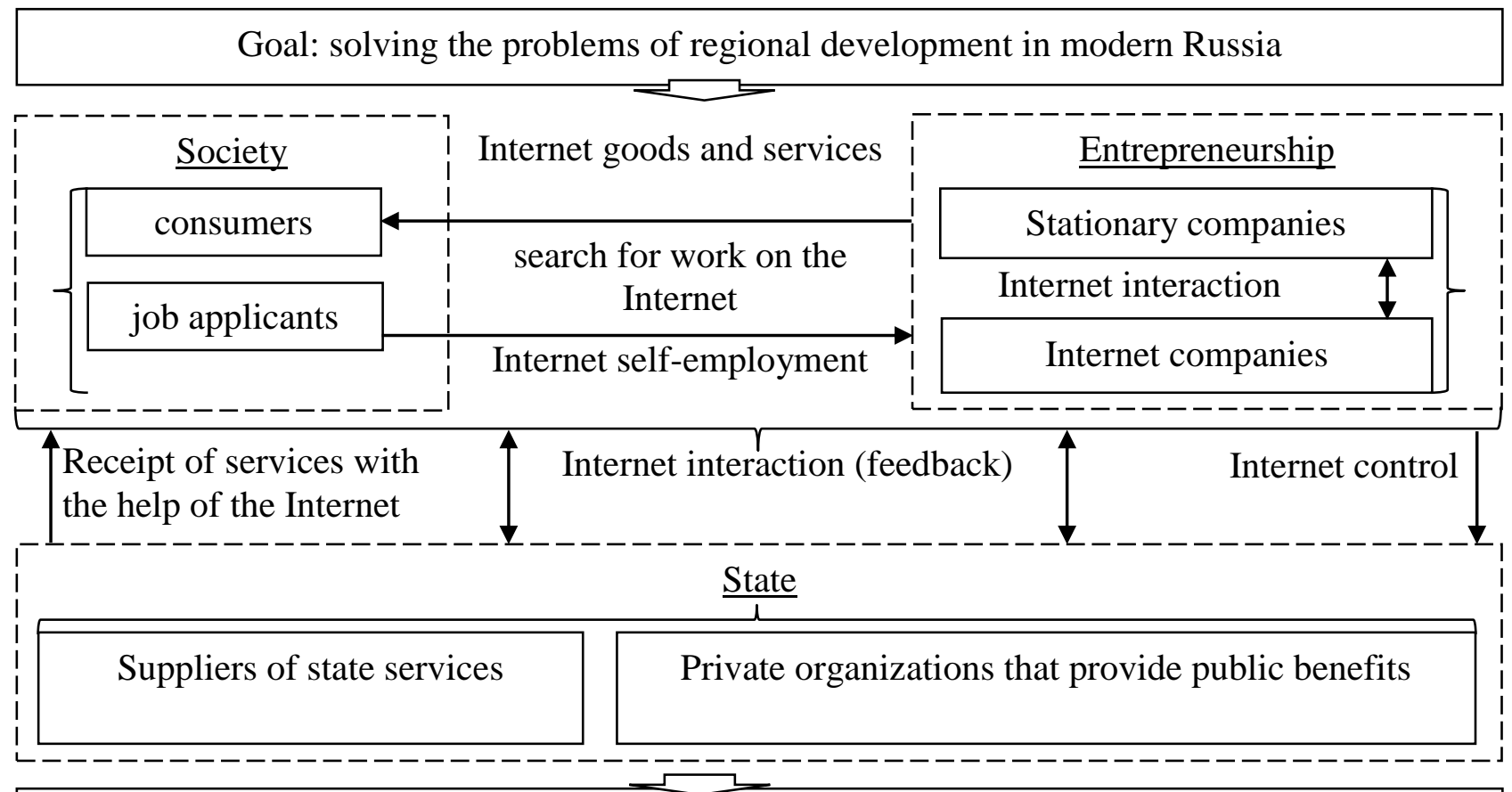

Result: increased provision of public benefits and state services, intensive development of economy (entrepreneurship), growth of employment and income, sustainable development of regional entrepreneurship

Fig 2. Model of solving the problems of regional development in modern Russia with the help of new Internet technologies Source: compiled by the authors

Figure 2 shows that application of Internet technologies should be oriented at activation of electronic interaction between non-government economic subjects and between them and the state. This interaction could (and should) take the following forms:

- Internet entrepreneurship (as self-employment), which allows increasing the level of business activity due to lower barriers of entering the sectorial markets for Internet companies that are characterized by low capital intensity;

- $\quad$ provision of Internet goods and services to consumers, for lower price, with larger choice, better terms of purchase (anytime anyplace) with similar quality, which allows increasing the volume of goods and services that are accessible to consumers with the same income;

- Internet interaction between stationary and Internet companies that opens wider possibilities for their integration (including, for example, clustering) and increase of positions in the market;

- $\quad$ search for a job on the Internet and employment in Internet companies that provide access to fuller list of vacancies, their comfortable classification and selection, and quick and convenient passing of interviews and hiring;

- $\quad$ receipt of state services with the help of the Internet (including, for example, electronic registration for an appointment to doctor), which allows increasing their accessibility (convenience of receipt);

- Internet control of provision of state services and public benefits, which supposes high level of transparency of this process by means of placing state reports on the Internet; 
The International Journal

ENTREPRENEURSHIP AND SUSTAINABILITY ISSUES

ISSN 2345-0282 (online) http://jssidoi.org/jesi/

2018 Volume 5 Number 4 (June)

http://doi.org/10.9770/jesi.2018.5.4(13)

- Internet interaction (feedback), which allows expressing public opinion (including dissatisfaction) regarding provision of state services and public benefits, setting requirements, and providing recommendations for their improvement.

Aggregate results include improved provision of public benefits and state services, intensive development of economy (entrepreneurship), growth of employment and income - i.e., successful complex solution of all determined problems of regional development in modern Russia.

\section{Discussion}

The additional advantage that appears as a result of implementing the developed model is sustainable development of regional entrepreneurship. In view of the fact that according to the modern scientific economic paradigm, entrepreneurship is the basis of functioning of economic systems (including regional systems), this advantage allows starting the process of economy's growth, thus ensuring not its short-term narrow effect but the complex chain of positive effects for region's economy.

It should be noted that all determined topical problems of regional development of modern Russia's economy are directly or indirectly related to sustainability of entrepreneurship and have the institutional nature. Thus, the second category of problems that are related to non-optimality of interaction between private economic subjects and the state is the reason for unsustainable development of entrepreneurship in modern Russia. As a matter of fact, this category of problems causes insufficient development and low effectiveness of institutional provision of entrepreneurial activities in the region.

The first category of problems that are related to non-optimality of interaction between private economic subjects is a result of unsustainable development of entrepreneurship in modern Russia. This category of problems causes insufficient development and low effectiveness of the very institute of regional entrepreneurship. Implementation of new Internet technologies into the regional socio-economic system allows solving the problems of regional development in modern Russia due to positive influence on the central link of these problems, by providing sustainability of regional entrepreneurship's development.

The institutional nature of the problems of regional development in modern Russia leads to their high complexity, as institutional changes require not only systemic measures of state regulation but also social (from society and business) approval and support. Therefore, successfulness of practical implementation of the compiled conceptual model of solving the problems of regional development in modern Russia with the help of new Internet technologies is largely determined by susceptibility and readiness of region's social environment to changes.

In order to reduce the risk component of implementation of the developed model, related to influence of social factors on this process, it is expedient to supplement it with measures in the sphere of adaptation of region's social environment to future changes in the sphere of implementation of new Internet technologies. For that, the following practice-oriented authors' recommendations are offered:

- $\quad$ establishment of the course at provision of sustainable development of entrepreneurship in the normative and legal provision of entrepreneurial activities in the region;

- $\quad$ implementation of measures in the sphere of social marketing, aimed at informing society and business on critical importance and necessity for sustainable development of regional entrepreneurship and planned methods of achievement of this goal;

- conduct a series of consultations for regional entrepreneurial structures on the issues of their sustainable development, including general theoretical issues of sustainable development of entrepreneurship and applied issues of transition of these structures to sustainable trajectory of development; 
The International Journal

ENTREPRENEURSHIP AND SUSTAINABILITY ISSUES

ISSN 2345-0282 (online) http://jssidoi.org/jesi/

2018 Volume 5 Number 4 (June)

http://doi.org/10.9770/jesi.2018.5.4(13)

- $\quad$ emphasis on sustainable development of entrepreneurship with state investments into modernization of regional socio-economic system on the basis of new Internet technologies.

Due to achievement of positive transformation changes in the institutional environment of regional socioeconomic system and achievement of sustainability of regional entrepreneurship's development, the problems of regional development in modern Russia will be solved for the long-term. Sustainable development of regional entrepreneurship will allow eliminating the existing problems and preventing most new problems of regional development in modern Russia.

\section{Conclusion}

Thus, the offered hypothesis was proved. It was substantiated that implementation of new Internet technologies is a perspective means of solving the problems of regional development in modern Russia. These problems concern the non-optimality of interaction between non-government economic subjects (society and entrepreneurship), which leads to low business activity, complexity of employment, unemployment rate, and low level of income, as well as non-optimality of interaction between non-government economic subjects and the state, which leads to inaccessibility and low quality of state services and public benefits, including healthcare, housing and utility sector, infrastructure, etc.

Implementation of new Internet technologies into entrepreneurship allows reducing its capital intensity, increasing business activity, simplifying the process of employment, and increasing accessibility (reducing the cost) of goods and services for population. Due to implementing new Internet technologies into activities of state organizations that provide state services and public benefits, their better controllability and manageability by society are achieved, which stimulates the increase of quality and accessibility.

The central link of the developed and presented authors' model of solving the problems of regional development in modern Russia with the help of new Internet technologies is sustainability of entrepreneurship. Unifying all existing problems of regional development in modern Russia, unsustainable entrepreneurship is the key institutional contradiction of regional socio-economic system. Implementation of new Internet technologies allows overcoming this contradiction, forming favorable institutional environment for establishment of sustainable entrepreneurship and ensuring formation of the institute of sustainable entrepreneurship in modern Russia's regions.

It should be noted that results of the performed research are limited by reflection of perspectives of solving the problems of regional development in modern Russia with the help of new Internet technologies, while the measures that are required for their practical implementation go beyond the limits of this work. These measures include creation and development of the corresponding normative \& legal and institutional provision and determine the perspectives of further scientific research.

The determined institutional nature of the problem of regional development in modern Russia emphasizes priority of study of the institutional aspect of solving these problems with the help of new Internet technologies. These problems are related to functioning of institutional provision of sustainable development of entrepreneurship in the region and establishment of the institute of sustainable development of entrepreneurship in region. That's why during further scientific research in continuation of this article it is expedient to include the tools of the neoinstitutional economic theory into the methodology. 


\section{References}

All-Russian Public Opinion Research Center. 2018. Actual problems that trouble Russians: press release No. 3396. Available on the Internet: https://wciom.ru/index.php?id=236\&uid=116269.

Bogoviz, A.V.; Ragulina, Y.V.; Komarova, A.V.; Bolotin, A.V.; Lobova, S.V. 2017. Modernization of the approach to usage of region's budget resources in the conditions of information economy development. European Research Studies Journal 20(3): 570-577.

Bogoviz, A.V.; Ragulina, Y.V.; Kutukova, E.S. (2016). Economic zones as a factor of increased economic competitiveness of the region. International Journal of Economics and Financial Issues 6(8Special Issue): 1-6.

Federal State Statistics Service (2018). Indicators for monitoring the evaluation of effectiveness of activities of the subjects of the Russian Federation. Available on the Internet: http://www.gks.ru/free_doc/new_site/rosstat/pok-monitor/pok-monitor.html (data accessed: 03.04.2018).

Golikova, G.V.; Franovskaya, G.N.; Dzyubenko, O.B. (2018). Analysis and problems of development of regional consumer complex. Advances in Intelligent Systems and Computing 622: 248-255. https://doi.org/10.1007/978-3-319-75383-6_32

Golova, I.M.; Sukhovey, A.F.; Nikulina, N.L. (2017). Problems of increasing the regional development innovative sustainability. Economy of Region 13(1): 308-318. https://doi.org/10.17059/2017-1-27

Inshakova A.O.; Goncharov A.I.; Sevostyanov M.V. (2017). Institutional Ambiguity of Regulation of Possessory Relations in Modern Russia. Overcoming Uncertainty of Institutional Environment as a Tool of Global Crisis Management 1(1): 207-212. https://doi.org/10.1007/978-3-319-60696-5_25

Kravets, A.G.; Gurtjakov, A.S.; Darmanian, A.P. (2013). Enterprise intellectual capital management by social learning environment implementation. World Applied Sciences Journal 23 (7): 956-964. https://doi.org/10.5829/idosi.wasj.2013.23.07.13120

Kuznetsov, S.Y.; Tereliansky, P.V.; Shuvaev, A.V.; Natsubize, A.S.; Vasilyev, I.A. (2016). Analysis of Innovate Solutions Based on Combinatorial Approaches. ARPN Journal of Engineering and Applied Sciences 11(17): 10222-10230.

Popova, L.; Litvinova, T.; Ioda, E.; Suleimanova, L.; Chirkina, M. (2015). Perspectives of the Growth of Economic Security by Clustering of Small Innovational Enterprises. European Research Studies Journal 18: 163-172.

Prangishvili, A.I.; Namicheishvili, O.M.; Gasitashvili, Z.; Ramazashvili, M.; Lekiashvili, L. (2017). Some problems of the regional development in Georgia. Information and Computer Technology, Modeling and Control: Proceedings of the International Scientific Conference Devoted to the 85th Anniversary of Academician I. V. Prangishvili: 337-348.

Przhedetskaya, N.V.; Akopova, E.S. (2016). Imperative of State in the Process of Establishment of Innovational Economy in the Globalizing World. European Research Studies 19(2): 79-85.

Ragulina, Y.V.; Bogoviz, A.V.; Alekseev, A.N. (2018). Modeling the management of innovational processes in regional economy. Advances in Intelligent Systems and Computing 622: 568-573. https://doi.org/10.1007/978-3-319-75383-6_72

RIA Ranking (2018). Ranking of socio-economic position of subjects of the Russian Federation - 2017. Available on the Internet: http://riarating.ru/regions/20170530/630063754.html (data accessed: 03.04.2018).

Shahraki, A.A. (2017). Regional development assessment: Reflections of the problem-oriented urban planning. Sustainable Cities and Society, 35: 224-231. https://doi.org/10.1016/j.scs.2017.07.021

Sibirskaya, E.V.; Shestaeva, K.A. (2016). The contents of innovative in the Russian Economy. KNOWLEDGE -ECONOMY - SOCIETY. Contemporary aspects of economic transformation. Edited by Pawel Lula, Tomast Pojer. Cracov Uniwersity of Economics. Krakow. Poland. p. 27-37.

Sukhodolov, A.P.; Popkova, E.G.; Kuzlaeva, I.M. (2018). Methodological aspects of study of internet economy. Studies in Computational Intelligence 714: 53-61. https://doi.org/10.1007/978-3-319-60273-8_5

Tvaronavičienè, M., Tarkhanova, E., \& Durglishvili, N. 2018. Sustainable economic growth and innovative development of educational systems, Journal of International Studies 11(1): 236-244. https://doi.org/10.14254/2071-8330.2018/11-1/19

Zemlickiene, V.; Mačiulis, A.; Tvaronavičienè, M. (2017). Factors impacting the commercial potential of technologies: expert approach, Technological and Economic Development of Economy 23(2): 410-427 http://dx.doi.org/10.3846/20294913.2016.1271061 


\section{Yulia V. RAGULINA}

Federal State Budgetary Scientific Institution "Federal Research Center of Agrarian Economy and Social Development of Rural Areas All Russian Research Institute of Agricultural Economics", Moscow, Russia

ORCID ID: 0000-0002-1177-0954

\section{Elena I. SEMENOVA}

Federal State Budgetary Scientific Institution "Federal Research Center of Agrarian Economy and Social Development of Rural Areas All Russian Research Institute of Agricultural Economics", Moscow, Russia

ORCID ID: 0000-0001-7227-9061

Irina A. ZUEVA

Moscow Witte University, Moscow, Russia

ORCID ID: 0000-0002-2770-4417

\section{Elena V. KLETSKOVA}

Federal State Budget Educational Institution of Higher Education “Altai State University”, Barnaul Russia

ORCID ID: 0000-0002-4694-1936

\section{Elena N. BELKINA}

Kuban State Agrarian University, Krasnodar, Russia

ORCID ID: 0000-0003-3334-6844

Register for an ORCID ID:

https://orcid.org/register 